\title{
Managing mentally abnormal offenders
}

\author{
JACK HaJioff, Consultant Psychiatrist, Hill End Hospital, St Albans AL4 0RB
}

Psychiatric patients often break society's rules and find themselves before the courts. Sometimes an offence is the first sign of mental illness. The coincidence of mental disorder and an offence complicates both assessment and management, but particularly the latter.

Before the 19th century mentally abnormal offenders did not constitute a special problem. As Kathleen Jones (1955) pointed out, before 1807 "criminal lunatics" were not distinguished from other criminals and all were sent to the county gaol or Bridewell. After 1807, with the development of the county asylum movement, most went to those institutions, although those convicted of more dangerous behaviour were still sent to prison.

Until the middle of the next century, there was an ebb and flow of mentally abnormal offenders between prisons and psychiatric hospitals. Henry Rollin has described a "stage army" of petty offenders moving in and out of a succession of institutions. It was a matter of chance whether such offenders were sent to prison or hospital.

More recently the enthusiastic pursuit of "opendoor" policies, the run-down and closure of large psychiatric hospitals and the move to community care have made it necessary to reconsider the management of this apparently unrewarding group.

Much has been written about dangerous offenders, their assessment, their placement in prisons and special hospitals, the criteria for their transfer to psychiatric hospitals and their eventual release into the community (Home Office \& DHSS, 1975; Hamilton \& Freeman, 1982).

Little has been said about the much more common mentally abnormal offenders who commit petty offences against property, trivial assaults, minor sexual offences and crimes connected with alcoholism (Bowden, 1977). The 'Butler Report' (Home Office \& DHSS, 1975) devotes only eight pages out of more than 300 to these offenders whom it describes as "inadequates". These offenders are limited or damaged personalities because of chronic schizophrenia, personality problems or mental handicap. They constitute a nuisance because of their poor response to conventional treatment; their limited co-operation and their recidivism. They are not popular in psychiatric hospitals or prisons, so that those writing Court Reports often try to direct them to other agencies. Probation officers and psychiatric hospitals each try to disclaim responsibility for the offender and emphasise those aspects which make it more appropriate for others to deal with.

The 'Butler Report' suggests more facilities to support these "inadequates" but nothing appears to have resulted from this recommendation, nor from similar advice given by an earlier report (Home Office \& DHSS, 1971).

Bowden (1977) carried out a survey of facilities and psychiatrists in the South East Thames Region and also looked at men remanded to Brixton Prison for medical reports. He concluded that facilities for chronically disabled mentally abnormal offenders were inadequate and that few of them required secure placement in either a regional secure unit or in prison. Nor, in my opinion, do many of them need treatment in psychiatric hospitals. Unfortunately, courts faced with such offenders for whom nothing satisfactory has been recommended by the reports before them feel obliged to deal with intractable problems by directing the offenders to prison or psychiatric hospital, both of which may be inappropriate and expensive options.

\section{Multidisciplinary assessment panel}

Awareness of this problem in North West Hertfordshire provoked discussions between probation officers and psychiatrists. These resulted in the formation of a multidisciplinary panel for the assessment of offenders. At first, the panel was constituted for a year as an experiment, but its success has led to its continuation. The original idea was mainly concerned with assessment but there has been a flowering of the collaborative process with a willingness to take on problems, aware that there is support available from other members of the panel. A community psychiatric nurse became involved very early in assessments and aftercare. Supportive groups have been established, conducted by community psychiatric nurses and probation officers. Magistrates and judges have supported the scheme; psychiatric teams in adjacent areas have shown an interest and some have adopted similar schemes.

The working of the assessment panel is best shown by comparing it to our previous practice. In the past an offender whom the court considered might be mentally disordered was remanded for three weeks for reports. During that adjournment the probation officer, a psychiatrist and possibly the prison medical officer, would see the offender and report 
independently. The court would consider these reports and a decision about management arrived at. If the offender was made subject to a probation order, with a condition of treatment involving attendance at a psychiatric clinic, there would be some communication between the probation officer and the psychiatrist. Magistrates told us that a disadvantage of this procedure was that they were often faced with conflicting reports and limited information, especially if the case was a minor one and the psychiatrist was not present in court.

With the assessment panel approach, a probation officer acts as co-ordinator and asks for reports from a psychiatrist, a probation officer and others where it seems appropriate, such as a psychotherapist or psychologist. Before the reports are finalised and presented to the court, members of the panel meet and discuss their findings and what resources there are for dealing with the offender. Others with knowledge of the offender, such as social workers, community psychiatric nurses and general practitioners, may be invited to participate in the discussion. Members of the panel are able to inform each other of a full range of options and take these into account when presenting their recommendations. To facilitate these more comprehensive assessments the St Albans and Dacorum Courts have allowed up to eight weeks adjournment. When courts other than these were involved, they were told about the panel and accepted requests for longer adjournments. The result is that the court receives reports which have considered the alternatives and presented them with some evaluation, but without usurping its decisions.

\section{Further developments}

Increased co-operation between various agencies was followed by other developments. Disordered offenders remaining in the community were offered. supportive meetings of the probation department. These were conducted by a probation officer and community psychiatric nurses and were evidently well accepted by the offenders because, in the temporary absence of the conductors, the members took it upon themselves to continue the meetings.

\section{Community psychiatric nurses}

Having found that management of patients in the community improved with the support of community psychiatric nurses, it was a logical step to incorporate them into our work with disordered offenders. The present arrangement is that a psychiatric nurse funded by the NHS spends half his time with offenders and half in normal community psychiatric nursing. He visits offenders in their homes, is involved with group therapy and may also participate in assessment visits to offenders in prison and in panel discussions on particular offenders.

\section{Communication with magistrates}

Local magistrates have accepted longer remands to enable the assessment panel to carry out its work and have told us that reports are much more useful than they were. As part of this collaboration, a survey of magistrates in Hertfordshire was carried out to make us more aware of particular points they would like us to bear in mind when making our assessments. All magistrates felt that danger to the community must be considered and most were more interested in questions of treatment and placement than those of aetiology or background. These precise requirements of magistrates have not been emphasised in writings on psychiatric court reports (Gibbens, 1974, Bluglass, 1979).

\section{Comment}

Mentally abnormal offenders have never been adequately dealt with. This is largely because resources are limited and tend to be directed to the small number of dangerous offenders while the majority who commit minor offences are sent to whichever institution or agency is prepared to accept them.

This haphazard approach is inefficient and wasteful. The cost of keeping people in prison or hospital is very high. With a collaborative and mutually supportive multidisciplinary approach more mentally abnormal offenders are maintained in the community with considerable financial savings. For those who have been in institutions, continuing support in the community is more easily arranged and co-ordinated.

We believe our approach is also more effective. During the time that we have adopted this method, the re-offending rate for the mentally abnormal offenders we have seen has fallen.

\section{References}

Bluglass, R. (1979) The psychiatric court report. Medicine, Science and the Law, 19, 121-129.

BOWDEN, P. (1977) The current management of the mentally disordered offender. Proceedings of the Royal Society of Medicine, 70, 881-884.

Gibbens, T. C. N. (1974) Preparing psychiatric court reports. British Journal of Hospital Medicine, 12, 278-284.

HAmilton, J. R. \& FreEman, H. (1982) Dangerousness, Psychiatric Assessment and Management. London: The Royal College of Psychiatrists.

Home Office and Department ofoHealth \& Social SeCURITY (1971) Report on the Working Party on Habitual Drunken Offenders. London: HMSO.

- (1975) Report of the Committee on Mentally Abnormal Offenders, (Chairman: Lord Butler), Cmnd 6244. London: HMSO.

JONES, K. (1955) Lunacy, Law and Conscience. London: Routledge \& Keagan Paul. 